\title{
CGB and GNRH1 expression analysis as a method of tumor cells metastatic spread detection in patients with gynecological malignances
}

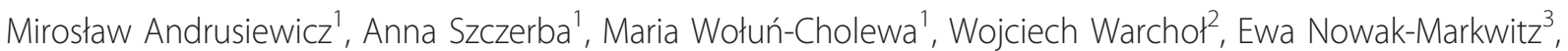
Emilia Gąsiorowska ${ }^{3}$, Krystyna Adamska ${ }^{4}$ and Anna Jankowska ${ }^{1 *}$

\begin{abstract}
Background: Metastasis is a common feature of many advanced stage cancers and metastatic spread is thought to be responsible for cancer progression. Most cancer cells are localized in the primary tumor and only a small population of circulating tumor cells (CTC) has metastatic potential. CTC amount reflects the aggressiveness of tumors, therefore their detection can be used to determine the prognosis and treatment of cancer patients. The aim of this study was to evaluate human chorionic gonadotropin beta subunit (CGB) and gonadoliberin type 1 (GNRH1) expression as markers of tumor cells circulating in peripheral blood of gynecological cancer patients, indicating the metastatic spread of tumor.
\end{abstract}

Methods: CGB and GNRH1 expression level in tumor tissue and blood of cancer patients was assessed by real-time RT-PCR. The data was analyzed using the Mann-Whitney $U$ and Spearman tests. In order to distinguish populations with homogeneous genes' expression the maximal likelihood method for one- and multiplied normal distribution was used.

Result: Real time RT-PCR results revealed CGB and GNRH1 genes activity in both tumor tissue and blood of gynecological cancers patients. While the expression of both genes characterized all examined tumor tissues, in case of blood analysis, the transcripts of GNRH1 were found in all cancer patients while CGB were present in 93\% of patients. CGB and GNRH1 activity was detected also in control group, which consisted of tissue lacking cancerous changes and blood of healthy volunteers. The log-transformation of raw data fitted to multiplied normal distribution model showed that CGB and GNRH1 expression is heterogeneous and more than one population can be distinguished within defined groups.

Based on CGB gene activity a critical value indicating the presence of cancer cells in studied blood was distinguished. In case of GNRH1 this value was not established since the results of the gene expression in blood of cancer patients and healthy volunteers were overlapping. However one subpopulation consists of cancer patient with much higher GNRH1 expression than in control group was found.

Conclusions: Assessment of CGB and GNRH1 expression level in cancer patients' blood may be useful for indicating metastatic spread of tumor cells.

Keywords: human chorionic gonadotropin beta subunit, gonadotropin releasing hormone type 1, real time RT-PCR, CTC

\footnotetext{
* Correspondence: ajanko@ump.edu.pl

'Department of Cell Biology, Poznan University of Medical Sciences,

Rokietnicka Street 5D, 60-806 Poznan, Poland

Full list of author information is available at the end of the article
} 


\section{Background}

Neoplastic diseases represent chaotic self-developing systems, in which genetically destabilized cells replicate themselves continuously [1]. Within each replication cycle they produce new, modified daughter cells $[2,3]$. The accumulation of genetic alternations increases genetic instability [4]. During this process several different cell lines with different gene expression profile might co-exist within one tumor [5-10]. Cancer cells and their metastatic progeny retain the capacity for self-evolution [1]. New cell variants are better adapted to local growth requirements and might survive or undergo apoptosis [11,12].

Tumors with a high degree of genetic instability are able to produce more cells, thereby providing a larger reservoir for new, better adapted variants. This corresponds to development from preneoplastic to invasive cancer and consequently worse prognosis $[4,13-15]$.

Some cancer cells posses the ability to penetrate the walls of blood vessels, circulate in the bloodstream and reach other niches of the body. These circulating tumor cells (CTC) are thought to be responsible for metastatic spread and cancer progression. Therefore detection of circulating tumor cells may be important for both diagnosis and treatment of cancer patients [16-19].

While most cancer cells (CC) are localized in the primary tumor, there is only a small population of circulating cancer cells having metastatic potential. The frequency of CTC occurrence in peripheral blood is estimated to be 1 cancer cell per $10^{5-7}$ mononuclear cells [20]. Nevertheless their presence and amount reflect the aggressiveness of tumors [21,22].

Recently highly sensitive methods have been developed to detect CTC in blood of cancer patients. These methods include flow cytometry, immunohistochemistry and real time RT-PCR [23-27]. Still, most of these methods do not seem to be sensitive enough to detect CTC in patients with early-stage carcinomas [28-31].

The objective of this study was to use quantitative real time RT-PCR and analyze the expression level of two genes: human chorionic gonadotropin beta subunit (CGB) and gonadotropin releasing hormone type 1 (gonadoliberin type 1, GNRH1) in order to detect CTC in peripheral blood of gynecological cancer patients. The research was undertaken to establish the sensitivity and specificity of the genes activity as an informative way to identify tumor cells of gynecological origin in blood of cancer patients, which can indicate metastatic spread of tumor cells.

These two genes were selected because a number of studies have demonstrated that their expression level is up-regulated in gynecological tumors [32-38].

Serum free CGB or its urinary degradation product beta-core fragments are found in $68 \%$ of ovarian, $51 \%$ of endometrial and $46 \%$ of cervical malignancies [32]. Our earlier study proved that CGB is expressed by analyzed gynecological tumor tissues [33-35]. The free beta subunit of human chorionic gonadotropin was originally considered as biologically non-functional, however it was shown recently that CGB may stimulate tumor growth and inhibit its apoptosis. This theory is supported by the results of $C G B$ genes silencing, showing that reduction of the hormone's expression in vitro resulted in increased apoptosis rate of cancer cells [36]. Furthermore elevated CGB level in serum was found to be associated with higher aggressiveness of cancer and its resistance to therapy [32].

In ovarian, endometrial, mammary, and prostate cancers significant level of GNRH1 expression was also detected and the agonists of GNRH1 have been shown to inhibit proliferation and stimulate apoptosis of ovarian and endometrial carcinoma cells [37]. We have previously demonstrated that the expression of $C G B$ in endometrial cancer as well as in endometrial atypical hyperplasia is accompanied by expression of gonadotopin releasing-hormone type 1 [38].

In this study we showed that the up-regulation of human chorionic gonadotropin beta subunit and gonadoliberin type 1 genes expression may indicate the presence of tumor cells circulating in peripheral blood of gynecological cancer patients. Thus, the expression of CGB and GNRH1 may become a prognostic factor of metastatic spread of tumor cells [38].

\section{Materials and methods Patients}

Surgical specimens of gynecological cancer tissue have been obtained from 48 patients (age range 36-79) treated with surgery at the Department of Gynecologic Oncology, Poznan University of Medical Sciences. Peripheral blood from 41 cancer patients (age range 36-79) was collected before surgery. None of the patients received chemo- or radiotherapy prior to the operation. Histology groups were as follows: ovarian carcinoma (25 cases; FIGO: I, $\mathrm{n}=4$; II, $\mathrm{n}=1$; III, $\mathrm{n}=14$; not determinate, $n=6$ ), endometrial carcinoma (14 cases, FIGO not evaluated), uterine cervix carcinoma ( 9 cases; FIGO $0, \mathrm{n}=1 ; \mathrm{I}, \mathrm{n}=4 ; \mathrm{II}, \mathrm{n}=2$; III, $\mathrm{n}=0$; not determinate, $\mathrm{n}=2$ ).

The control group consisted of blood from 43 healthy volunteers (age range 21 - 56) and 12 control tissue samples lacking pathological changes. The absence of cancerous changes has been confirmed by anatomicopathologic macroscopic and microscopic examinations. These tissue samples were obtained from patients operated for reasons other than cancer. The study was approved by the Institutional Ethics Review Board of Poznan University of Medical Sciences. All patients and 
volunteers participated in the research after obtaining informed consent.

\section{Sample collection}

$9 \mathrm{ml}$ of blood from the patients and from the volunteers was collected in S-monovette tubes (SARSTEDT AG \& Co., Numbrecht, Germany). The blood samples where diluted with PBS (without $\mathrm{Ca}^{2+}$ and $\mathrm{Mg}^{2+}$ ) up to $17 \mathrm{ml}$. The PfU blood separation tubes and LSM 1077 separation medium (PAA Laboratories GmbH, Pasching, Austria) were used to separate the cells during centrifugation at $1200 \times \mathrm{g}$ for 20 minutes at room temperature in a swinging bucket rotor. Cells located in the interphase were collected and washed twice with $10 \mathrm{ml}$ of PBS. The cells were resuspended in $1.5 \mathrm{ml}$ TRIzol LS Reagent (Invitrogen, CA, USA) and stored at $-80^{\circ} \mathrm{C}$ until total RNA isolation was performed.

Tissue samples from patients after surgical removal were placed in RNALater and stored at $-80^{\circ} \mathrm{C}$.

\section{RNA isolation and CDNA synthesis}

Total cellular RNA from blood and tissue samples was extracted with TRIzol LS Reagent (Invitrogen) and TriPure Isolation Reagent (Roche Diagnostic $\mathrm{GmbH}$, Mannheim, Germany) respectively, according to manufacturer's protocols. RNA purity and concentration was determined spectrophotometrically and electrophoretically in $1.2 \%$ agarose gel containing $1.5 \%$ formaldehyde (Sigma-Aldrich, USA) in FA buffer (20 mM MOPS, $5 \mathrm{mM}$ sodium acetate, 1 mM EDTA, 200 mM paraformaldehyde; pH 7.0; SigmaAldrich).

$2 \mu \mathrm{g}$ of total RNA was used for cDNA synthesis. Mixture of RNA, universal oligo(d) $\mathrm{T}_{10}$ primer and RNasefree water was incubated at $65^{\circ} \mathrm{C}$ for 10 minutes in order to denature RNA secondary structure. Then the mixture was placed on ice and other components: $500 \mathrm{mM}$ dNTPs, $10 \mathrm{nM}$ DTT, $20 \mathrm{U}$ ribonuclease inhibitor, $5 \times$ reverse transcriptase buffer and $50 \mathrm{U}$ of Transcriptor Reverse Transcriptase were added. mRNA was reversely transcribed at $55^{\circ} \mathrm{C}$ for 30 minutes. It was followed by enzyme inactivation at $85^{\circ} \mathrm{C}$ for 5 minutes. cDNA was placed on ice or stored at $-20^{\circ} \mathrm{C}$ until real time PCR was performed. All compounds used for cDNA synthesis were purchased from Roche Diagnostic (Roche Diagnostic, Mannheim, Germany).

\section{Real time PCR}

To asses the expression level of CGB [NCBI: NM_000737] and GNRH1 [NCBI: NM_000825.3] genes real time PCR with sequence specific primers and LightCycler ${ }^{\circledR}$ TaqMan ${ }^{\circledR}$ Master Kit (Roche Diagnostics) has been performed. PCR reaction mixture contained: $5 \mu \mathrm{l}$ of cDNA, 1x TaqMan Master mix, $0.1 \mu \mathrm{M}$ hydrolysis probe (TaqMan) and $0.5 \mu \mathrm{M}$ of the primers. The primers were designed to be complementary to the splice junction, what excluded the possibility of DNA amplification. Hydrolysis probes and primers used are described in table 1. TaqMan hydrolysis probe for examined genes and phosphoribosyltransferase (HPRT) housekeeping gene were purchased from Universal Probe Library (Roche Diagnostic).

The program of PCR consisted of 1 cycle of $95^{\circ} \mathrm{C}$ with a 10 minute hold, followed by 45 cycles of $95^{\circ} \mathrm{C}$ with a 10 seconds hold, annealing/amplification temperature at $60^{\circ} \mathrm{C}$ with a 30 seconds hold, and $72^{\circ} \mathrm{C}$ with a 1 seconds hold for fluorescence data acquisition.

All experiments were performed in triplicates. PCR efficiencies were calculated from the standard curves (SC) generated using serial decimal dilutions of cDNA synthesized from placenta. A relative expression level of analyzed genes was normalized with control gene $H P R T$. The final step of the expression level analysis was the calculation of the CGB/HPRT and GNRH1/ $H P R T$ concentration ratio $(\mathrm{Cr})$.

The PCR products were sequenced to confirm their identity.

\section{Data collection and Statistical analysis}

Real time PCR data was assembled using the LightCycler computer application software 4.05 dedicated for the LightCycler 2.0. All data was analyzed using the Statistica Software ver. 6.0 (StatSoft, Poland).

The Mann-Whitney U test was performed and the differences were considered to be statistically significant if $P$-value was lower than 0.05 .

$C G B$ and GNRH1 concentration ratios were log-transformed to achieve normal distribution of data.

In order to distinguish populations with homogeneous genes' expression the maximal likelihood method for oneand multiplied normal distribution was used.

Relative levels of CGB and GNRH1 expression between studied groups were correlated using Spearman's Rank Correlation test and the results were considered to be statistically significant if $P$-value was lower than 0.05 .

\section{Results}

The expression of CGB and GNRH1 was evaluated for gynecological tumor tissue and peripheral blood of patients with gynecological cancer using real time RTPCR method. PCR products identity was confirmed by sequencing.

The results of the study demonstrated that both genes are active in all analyzed tumors samples. Although the genes activity can be detected in control tissue lacking cancerous changes, the level of expression was significantly lower than the one found in cancer tissues (Figure 1 and 2). The differences between $C G B$ and GNRH1 genes expression in cancer tissue and healthy tissue was found 
Table 1 Primers and hydrolysis probes used in real-time PCR

\begin{tabular}{llll}
\hline Gene & TaqMan probe No & Forward primer $\mathbf{5}^{\prime} \rightarrow \mathbf{3}^{\prime}$ & Reverse primer $\mathbf{5}^{\prime} \rightarrow \mathbf{3}^{\prime}$ \\
\hline CGB & \#71 & TACTGCCCCACCATGACC & CACGGCGTAGGAGACCAC \\
& Roche Diagnostic, Cat. No: 04688945001 & & CTTCTGGCCCAATGGATTTA \\
\hline GNRH1 & \#29 & GACCTGAAAGGAGCTCTGGA & \\
& Roche Diagnostic, Cat. No: 04687612001 & & \\
\hline HPRT & Human HPRT Gene Assay (Roche Diagnostic, Cat. No: 05046157001) & \\
\hline
\end{tabular}

to be statistically significant $(P=0.000000$ and $P=$ 0.001037 , respectively).

$C G B$ and $G N R H 1$ transcripts were found also in peripheral blood of gynecological cancer patients as well as in blood of healthy volunteers (Figure 3 and 4). Nonetheless $C G B$ expression in blood of healthy volunteers and patients with cancer differed significantly $(P=$ 0.001066) and was higher in blood of cancer patients. In case of GNRH1 analysis the difference of the gene activity between studied groups was not statistically significant; $P=0.6098$.

Due to the nature of the measurement real time RTPCR data was log-transformed and then analyzed against existence of potential subpopulations varying in gene expression. Models of one, two and three coexisting subpopulations were taken into account and then evaluated using the maximal likelihood method. The outcome of this analysis was tested with F-test to assess the improvement of quality of the fit. Model of higher complicity (with greater number of subpopulations) was selected only if statistical significance of improvement $(P<0.05)$ was achieved. Additional verification of correctness of the chosen model was performed using Kolmogorov-Smirnov test. In this test all cases obtained $P>0.7$. The final results showed that the model, which assumes the presence of more than one normal distribution components, is significantly better for describing heterogeneous expression of CGB and GNRH1 genes within studied groups.
In case of $C G B$ expression analysis in tissues lacking cancerous changes only one distribution of results for each group was established (Figure 1A; Table 2). CGB expression in tumor tissues was categorized into two normal distributions (Figure 1B; Table 2). One of these distributions characterized by low level $C G B$ activity (mean of $\log _{10}$ of $C G B$ expression: -2.13, Table 2) corresponded to the results obtained for tumor blood (mean of $\log _{10}$ of $C G B$ expression: -2.34, Table 2). The other one with distinctly higher level of the gene expression (mean of $\log _{10}$ of $C G B$ expression: -1.35, Table 2) was typical for cancer tissue only.

The blood of cancer patients was characterized by one distribution of $C G B$ expression only (Figure $3 \mathrm{~B}$ ) while blood of healthy volunteers was categorized into two subpopulations (Figure 3A).

$C G B$ expression analysis in healthy volunteers' blood showed that this group can be divided into two subpopulations: one with low expression (smaller than -6.56) and the second one with high expression level of CGB $(-3.80)$. The second population partially overlaps with distribution of $C G B$ expression found for blood of cancer patients. Thus, in this particular case instead of usually using three sigma rules we applied -2.5 value to estimate the confidence limit, in which $95 \%$ of healthy volunteer had expression lower then critical value typical for cancer patients.

The raw results of GNRH1 expression were fitted to one, two or three coexisting subpopulations, each with

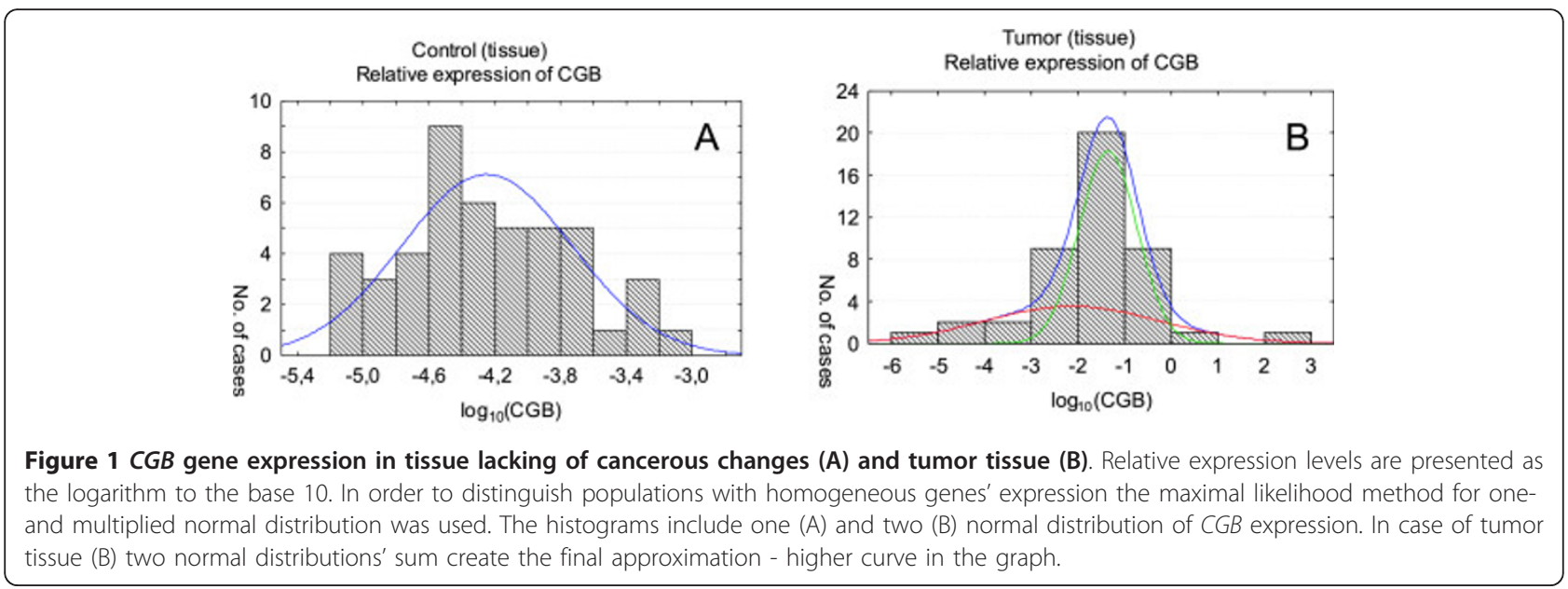



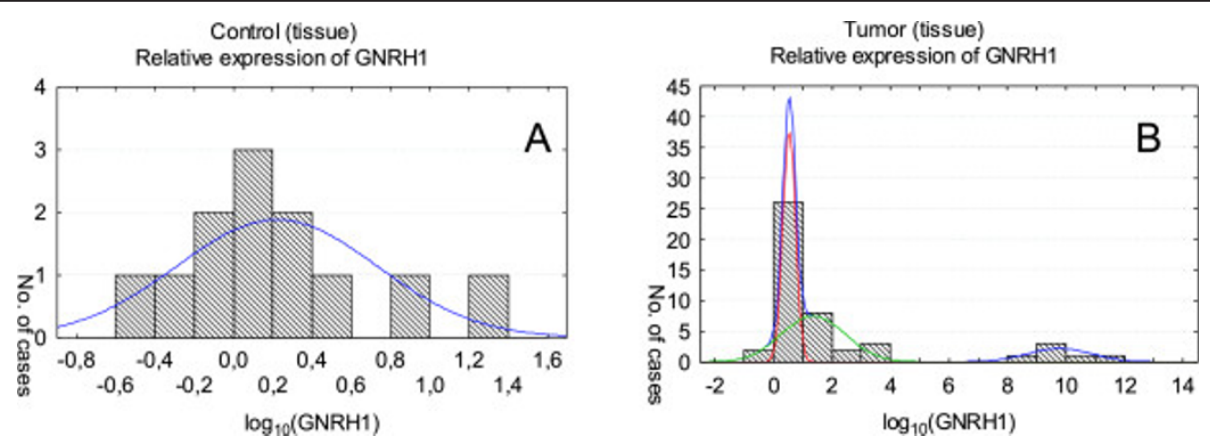

Figure 2 GNRH1 expression in tissue lacking cancerous changes (A) and tumor tissue (B). Relative expression levels are presented as the logarithm to the base 10. The maximal likelihood method for one- and multiplied normal distribution of GNRH1 expression was used and one normal distribution was obtained for control tissue (A) where for tumor tissue three normal distribution was found (B). The higher curve presented on the graph represents the sum of these three distributions (B).

normal distribution, and the model showed that one and two subpopulations can be set in control tissue lacking cancerous changes (Figure 2A) and control blood of healthy volunteers (Figure 4A), respectively (Table 2). In tumor tissue and blood of cancer patients three subpopulations with different levels of GNRH1 expression were established (Figure 2B and $4 \mathrm{~B}$ ).

Log-transformed results of GNRH1 expression in blood of cancer patient and in tumor tissue showed remarkably similar distributions (Figure $2 \mathrm{~B}$ and $4 \mathrm{~B}$, Table 2). Two of these distributions found in tumor blood corresponded to lower level of the gene activity (GNRH1 mean in tumor blood: 0.79 and 1.13 and in tumor tissue: 0.54 and 1.37). Furthermore in both cases the distribution matched to extremely high activity of GHNRH (Figure 2B and 4B) was found.

For GNRH1 critical value was not established since the results of the gene expression in blood of cancer patients and healthy volunteers were overlapping.
No correlation between $C G B$ and GNRH1 expression (Table 3) as well as clinical data (Table 4) in studied tissues and blood was observed.

\section{Discussion}

The critical role of circulating tumor cells in metastatic spread of carcinomas has already been very well documented. However the biology of these cells is poorly understood and the clinical relevance of their detection is still the subject of controversies. Available markers fail to distinguish between subgroups of CTC, and several current methods of CTC characterization and detection lack sensitivity, specificity and reproducibility [39].

Still early detection of these cells can become a useful method allowing the identification of cells with metastatic potential, and thus may be important for treatment and monitoring of cancer patients. RT-PCR based techniques and expression analysis of epithelial- and tissue-specific
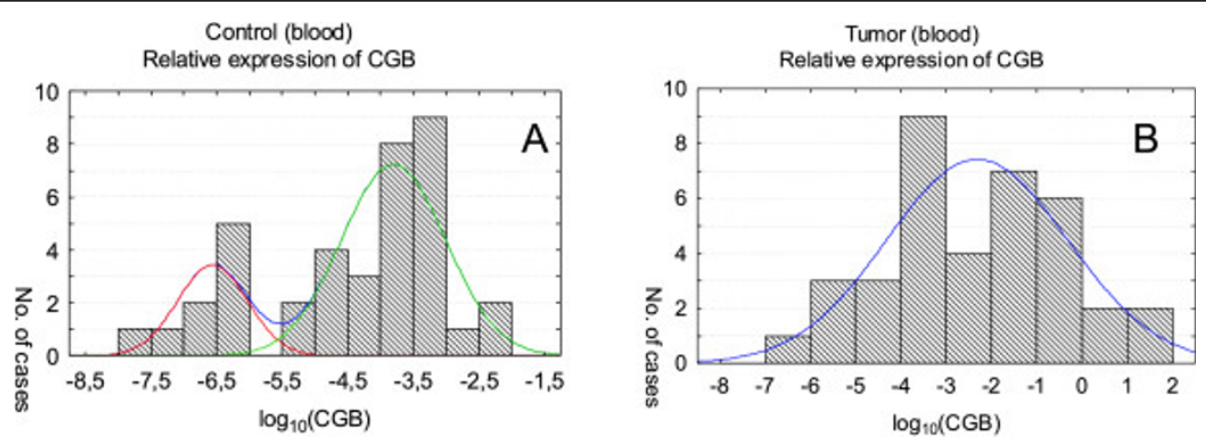

Figure 3 CGB expression in peripheral blood of healthy volunteers (A) and patients with cancer (B). Relative expression levels are presented as the logarithm to the base 10. CGB activity was fitted to two (A) and one normal distribution (B) in blood of healthy volunteers and cancer patients, respectively. The final approximation of CGB expression curve in control blood (A) is hidden due to the presence of nonoverlapping components. 

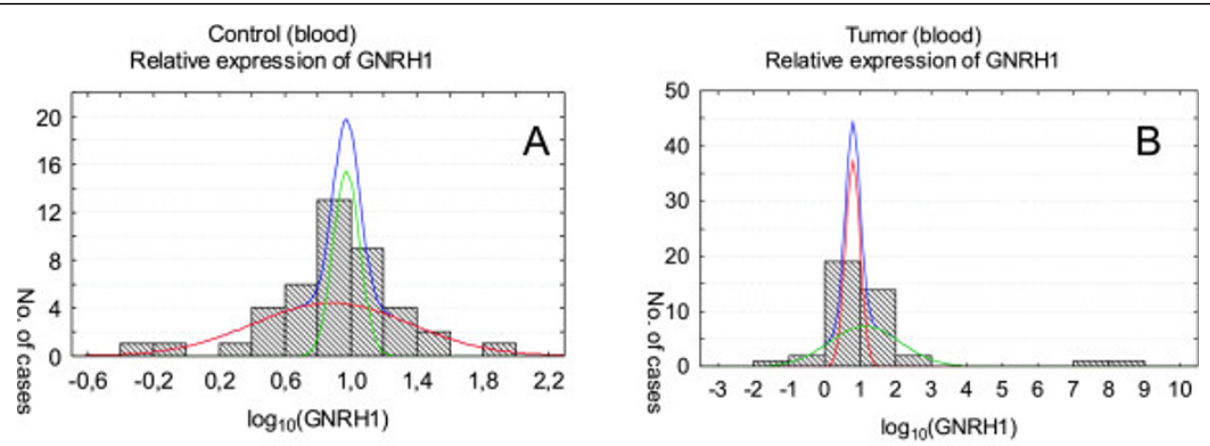

Figure 4 GNRH1 expression in peripheral blood of healthy volunteers (A) and patients with cancer (B). Relative expression levels are presented as the logarithm to the base 10. Analysis of GNRH1 expression blood of healthy volunteers (A) and patients with cancer (B) in both cases showed two distributions of results. The higher curve represents the sum of these two distributions.

markers are the most sensitive methods for CTC detection. Results of numerous studies indicate that detection of single mRNA markers like mamoglobin, survivin, HER2, EGFR, VEGF and VEGFR range from 30 to $63 \%$ cases in peripheral blood of breast cancers. After combination of a few markers as one single panel the sensitivity usually increases [40]. A panel of six genes: CCNE2, DKFZP1312, PPIC, EMP2, MAL2 and SLC6A8 may serve as potential markers for CTC derived from breast, endometrial, cervical, and ovarian cancers [41]. Also mamoglobin gene expression is a sensitive molecular marker for tumor spread detection in not only in patients with breast cancer but also gynecological neoplasms [42]. CTC presence analyzed with Adna Breast Test (detection of EpCAM-, MUC-1-, and HER-2-transcripts) together with CA 125 assessment were shown to be of prognostic significance in gynecological cancers [43]. Similarly endothelial progenitor cell expressing CD43 and VEGFR2 circulating in the blood of patients with ovarian cancer may be a potential marker to monitor cancer progression and angiogenesis as well as treatment response [44].

Our study identifies two mRNA markers of gynecological cancers: human chorionic gonadotropin beta subunit (CGB) and gonadotropin releasing-hormone type 1 (GNRH1), which enable detection of circulating tumor cells.

We have previously demonstrated that CGB is a valuable marker of tumor tissue of uterine cervix, endometrium and ovary. $C G B$ gene activity in cancer and atypical hyperplasia of endometrium is accompanied by the expression of gonadoliberin type 1 , which physiologically stimulates the synthesis and secretion of gonadotropins [33-35].

In this study the presence of cells expressing $C G B$ and GNRH1 in tumor tissue and blood of gynecological cancer patients was confirmed with real time RT-PCR. The results demonstrated that both genes are active in all analyzed tumor samples. CGB and GNRH1 transcripts were detected also in control tissue lacking cancerous changes, however the expression level of $C G B$ gene in control group was significantly statistically lower than in cancer group. Similarly both genes expression was demonstrated in peripheral blood of gynecological cancer patients as well as in control group consisting of healthy volunteers' blood. The level of CGB expression in blood of cancer patients and in blood of healthy volunteers

Table 2 The distributions of CGB and GNRH1 genes expression within studied groups

\begin{tabular}{|c|c|c|c|c|c|c|c|c|c|}
\hline \multirow[t]{2}{*}{ Material } & \multicolumn{3}{|c|}{ I } & \multicolumn{3}{|c|}{ II } & \multicolumn{3}{|c|}{ III } \\
\hline & $\begin{array}{c}\text { Subpopulation } \\
{[\%]}\end{array}$ & Mean & SD & $\begin{array}{c}\text { Subpopulation } \\
{[\%]}\end{array}$ & Mean & SD & $\begin{array}{c}\text { Subpopulation } \\
{[\%]}\end{array}$ & Mean & SD \\
\hline CGB Tumor (tissue) & 36.8 & -2.13 & 1.87 & 63.2 & -1.35 & 0.62 & & & \\
\hline CGB Control (tissue) & 100 & -4.25 & 0.51 & & & & & & \\
\hline CGB Tumor (blood) & 100 & -2.34 & 1.98 & & & & & & \\
\hline CGB Control (blood) & 24.2 & -6.56 & 0.53 & 75.8 & -3.80 & 0.79 & & & \\
\hline GNRH1 Tumor (tissue) & 43.5 & 0.54 & 0.22 & 43.4 & 1.37 & 1.08 & 13.1 & 9.79 & 1.10 \\
\hline GNRH1 Control (tissue) & 100 & 0.21 & 0.50 & & & & & & \\
\hline GNRH1 Tumor (blood)* & 49.0 & 0.79 & 0.21 & 46.0 & 1.13 & 1.00 & $5.0^{*}$ & * & * \\
\hline GNRH1 Control (blood) & 63.0 & 0.88 & 0.48 & 37.0 & 0.97 & 0.08 & & & \\
\hline
\end{tabular}

SD - standard deviation; * - two cases were excluded because they were found more then 10000 times higher than rightmost case from others. 
Table 3 The correlation between CGB and GNRH1 genes expression within studied groups

\begin{tabular}{lc}
\hline Material & $\begin{array}{c}\text { CGB/GNRH1 } \\
\boldsymbol{P} \text { value }\end{array}$ \\
\hline Tumor (tissue) & 0.128 \\
\hline Control (tissue) & 0.164 \\
\hline Tumor (blood) & 0.115 \\
\hline Control (blood) & -0.089 \\
\hline
\end{tabular}

Statistical significance $P<0.05$.

differed significantly while GNRH1 activity in the studied groups was not statistically significant.

Due to the nature of real time RT-PCR measurement the levels of $C G B$ and $G N R H 1$ relative expression were log-transformed and fitted to multiplied normal distribution model using the maximal likelihood method. The results of the conversions showed that the model assuming the presence of more than one normal distribution components improved the description of heterogeneous expression of studied genes.

Analysis of $C G B$ and GNRH1 expression in tissue lacking cancerous changes showed one distribution of results for both genes. In case of tumor tissue $C G B$ and GNRH1 activity were fitted into two and three normal distribution, respectively. The first population showing lower expression of $C G B$ (mean of $\log _{10}$ of $C G B$ expression: -2.13 ) consisted of $36.8 \%$ of tissues, while the second with higher $C G B$ activity (mean of $\log _{10}$ of $C G B$ expression: -1.35 ) included $63.2 \%$ of samples. Two distribution of GNRH1 with lower (mean: 0.54) and higher expression level (mean: 1.37) comprised of almost the same number of analyzed tissues (43.5\%). The third distribution corresponded to the maximum gene activity with mean of $\log _{10}$ GNRH1 expression equal to 9.79 and includes $13 \%$ of examined samples. These samples may represent tissues producing maximal level of GNRH1 or tissue fragments containing higher number of cancer cells. Immunohistochemical analysis could verify these hypotheses

$C G B$ and GNRH1 activity was studied also in blood of gynecological cancer patients and was compared to the control blood of healthy volunteers.

In control blood both genes were fitted into two distributions. However, GNRH1 distributions overlapped

Table 4 The correlation between CGB and GNRH1 genes expression in different cancer types

\begin{tabular}{lc}
\hline Material & $\begin{array}{c}\text { CGB/GNRH1 } \\
\boldsymbol{P} \text { value }\end{array}$ \\
\hline Enodometrial cancer & 0.961 \\
\hline Ovarian & 0,234 \\
\hline Uterix & 0,932 \\
\hline
\end{tabular}

Statistical significance $P<0.05$. (mean: 0.88 and 0.97 ) and $C G B$ distributions were separated from each other (mean: -6.56 and -3.8 ). The results showed that in case of CGB analysis in $95 \%$ of the population the gene expression is lower than -2.5 , which indicates the lack of circulating tumor cells. In contrast $5 \%$ of control blood was shown to have $C G B$ expression higher than -2.5 . Thus, this critical value may be used to indicate the metastatic spread of tumor.

There is no defined explanation of CGB and GNRH1 activity noted both in control tissue lacking cancerous changes and blood of healthy volunteers. False-positive CG cases have been already reported before, though the elevated level of the hormone was detected only on protein level [45-48]. In these cases the presence of heterophilic antibodies was thought to be the reason for falsepositive CG. In our study the activity of $C G B$ and GNRH1 was detected on mRNA level. Sequence specific primers and hydrolysis probes used in real time PCR study excluded the possibility of false-positive results in case of both genes amplification. This implies that cells with altered gene expression can exist in healthy tissue. Even if the number of these cells is very small high sensitivity of real time RT-PCR enables their detection. Consequently, not only the presence of genes' transcripts but also the level of their expression should be verified in case of tumor cells detection.

Analysis of $C G B$ expression transformed results in blood of gynecological patients revealed the presence of one distribution. One of the two distributions found in control group overlapped partially with $C G B$ detected in cancer patients. Nonetheless maximal $C G B$ expression level found is some cancer patients was $10^{5}$ higher than maximal activity of the gene of given healthy volunteers. Thus, it may be concluded that the high activity of human chorionic gonadotropin beta subunits indicated the presence of tumor cells circulating in blood of patients.

The raw results of GNRH1 expression in blood of cancer patients was fitted to three normal distributions. Two of these distributions corresponding to lower level of the gene activity (mean of $\log _{10}$ of GNRH1 expression: 0.79 and 1.13) were similar to these observed in tumor tissue and control blood. Additionally in blood of cancer patients as well as in tumor tissue a third subpopulation corresponding to extremely high activity of GNRH1 (Figure 2B and 4B) was found. This activity was $10^{5}$ higher than in other cases which may indicate patients in metastasis stage.

Analysis of results demonstrated that in part of the studied blood samples of cancer patients activity of $C G B$ and GNRH1 was on the same level as in control group. There is no defined explanation of this fact, however some possibilities should be considered. The simplest one is based on the presumption that examined patients 
simply lacked CTC, which is probably especially that patients in early cancer stages were examined. Another possibility is that the cells were present but their number was so small that we were not able to detect them. In fact many authors admit to the inability to detect circulating tumor cells because of their small number, indicating insufficient capacity of CTC isolation methods [49]. Another possibility is that tumor progression enhances its heterogeneity, clonal selection, and variable expression of individual mRNA markers [50,51].

When designing this study, we assumed that cancer cells that spread from a primary tumor, and penetrate the bloodstream have metastatic potential and show a similar profile of gene expression to the cells present in the initial tumor mass. According to the theory of tumor cellular heterogeneity and its genetic instability once CTC detach from a primary tumor they may change their expression profile, adapting to new microenvironment [52]. What is more it can not be excluded that analysed gynecological cancer types might not metastasize primarily via the hematogenous route, thus CTC could be even rarer events than expected.

Still based on the results of analyzed genes activity in blood of volunteers and cancer patients the presence of cancer cells can be distinguished. High expression level in case of $C G B$ and GNRH1 expression allowed identifying four and two individuals, respectively as cancer patients having tumor cell circulating in the blood flow. High CGB activity was found in blood of three patients with ovarian carcinoma (FIGO II, $\mathrm{n}=1$; III, $\mathrm{n}=2$ ) and one patient with endometrial cancer. GNRH1 expression was detected in two patients with ovarian carcinoma (FIGO II, $\mathrm{n}=1$; III, $\mathrm{n}=1$ ). The expression level of the genes assessed in blood of these patients was $10^{5}$ higher than the genes activity observed in control group.

Our study demonstrated that CTC-related markers' expression may be heterogeneous therefore establishing a critical level of genes expression may be useful in order to recognize the spread of cancer cells. Defining such a "cutoff value" may be applied not only for $C G B$ and GNRH1 expression but also other genes used as CTC markers. Especially that most of previously published data are limited to showing the percentage of positive cancer patients without any presentation of the number of positive healthy controls [40].

No correlation between $C G B$ and GNRH1 expression in studied tissues and bloods as well as clinical data was observed $(P>0.05)$. This suggests that analyzed genes' expression profiles are independent of one another as well as of cancer type. The studies on the mechanisms regulating these genes activity may help explain the observed phenomenon.

\section{Conclusions}

The assessment of human chorionic gonadotropin beta subunit and gonadoliberin type 1 expression levels in blood of cancer patients may allow distinguishing patients with tumor cells circulating in their blood and indicate the metastatic spread of these cells.

\section{Acknowledgements}

This study was supported by the Polish Ministry of Science and Higher Education Awards: NN 407109533, NN 407275439.

\section{Author details}

${ }^{1}$ Department of Cell Biology, Poznan University of Medical Sciences, Rokietnicka Street 5D, 60-806 Poznan, Poland. ²Department of Biophysics, Poznan University of Medical Sciences, Fredry Street 10, 61-701 Poznan, Poland. ${ }^{3}$ Department of Gynecologic Oncology, Poznan University of Medical

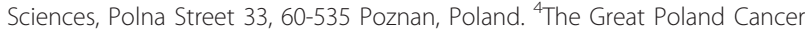
Center in Poznan, Garbary Street 15, 61-688 Poznan, Poland.

\section{Authors' contributions}

AM, AS, AJ participated in the study design, carried out the molecular genetic studies and performed data analysis. AJ has been involved in coordination of the study and drafting the manuscript. MWC, WW performed the statistical analysis and interpretation of data. ENM, EG, KA collected surgical tissue and blood samples, performed anatomicopathologic macroscopic and microscopic examinations and delivered clinical patients' data. All authors read and accepted the final manuscript.

\section{Competing interests}

The authors declare that they have no competing interests.

Received: 30 December 2010 Accepted: 9 August 2011

Published: 9 August 2011

\section{References}

1. Crespi B, Summers K: Evolutionary Biology of Cancer. Trends Ecol Evol 2005, 20:545-552.

2. Merlo LM, Pepper JW, Reid BJ, Maley CC: Cancer as an evolutionary and ecological process. Nat Rev Cancer 2006, 6:924-935.

3. Coffey DS: Self-organization, complexity and chaos: the new biology for medicine. Nat Med 1998, 4:882-885.

4. Hanahan D, Weinberg RA: The hallmarks of cancer. Cell 2000, 100:57-70.

5. Fujii H, Marsh C, Cairns P, Sidransky D, Gabrielson E: Genetic divergence in the clonal evolution of breast cancer. Cancer Res 1996, 56:1493-1497.

6. Shankey SE, Shankey TV: Genetic and phenotypic heterogeneity of human malignancies: finding order in chaos. Cytometry 1995, 21:2-5

7. Zhang W, Grossman D, Takeuchi S: Colonization of adjacent stem cell compartments by mutant keratinocytes. Semin Cancer Biol 2005, 15:97-102.

8. Braakhuis BJ, Leemans CR, Brakenhoff RH: Expanding fields of genetically altered cells in head and neck squamous carcinogenesis. Semin Cancer Biol 2005, 15:113-120.

9. Maley CC, Galipeau PC, Finley JC, Wongsurawat VJ, Li X, Sanchez CA, Paulson TG, Blount PL, Risques RA, Rabinovitch PS, Reid BJ: Genetic clonal diversity predicts progression to esophageal adenocarcinoma. Nature Genet 2006, 38:468-473.

10. Gonzalez-Garcia I, Sole RV, Costa J: Metapopulation dynamics and spatial heterogeneity in cancer. Proc Natl Acad Sci USA 2002, 99:13085-13089.

11. Nunney L: The population genetics of multistage carcinogenesis. Proc Biol Sci 2003, 270:1183-1191.

12. Michor F, Frank SA, May RM, Iwasa $Y$, Nowak MA: Somatic selection for and against cancer. J Theor Biol 2003, 225:377-382.

13. Duesberg P, Rausch C, Rasnick D, Hehlmann R: Genetic instability of cancer cells is proportional to their degree of aneuploidy. Proc Natl Acad Sci USA 1998, 95:13692-13697.

14. Loeb LA: Cancer cells exhibit a mutator phenotype. Adv Cancer Res 1998 72:25-56. 
15. Berman JJ, Moore GW: The role of cell death in the growth of preneoplastic lesions: a Monte Carlo simulation model. Cell Prolif 1992, 25:549-557.

16. Watanabe $Y$, Satou T, Nakai H, Etoh T, Dote K, Fujinami N, Hoshiai H: Evaluation of parametrial spread in endometrial carcinoma. Obstet Gynecol 2010, 116:1027-1034.

17. Chiang AC, Massagué J: Molecular basis of metastasis. N Engl J Med 2008, 359:2814-2823

18. Gerges N, Rak J, Jabado N: New technologies for the detection of circulating tumour cells. Br Med Bull 2010, 94:49-64.

19. Jacob K, Sollier C, Jabado N: Circulating tumor cells: detection, molecular profiling and future prospects. Expert Rev Proteomics 2007, 4:741-756.

20. Ross AA, Cooper BW, Lazarus HM, MacKay W, Moss TJ, Ciobanu N, Tallman MS, Kennedy MJ, Davidson NE, Sweet D, Winter C, Akard L, Jansen J, Copelan E, Meagher RC, Herzig RH, Klumpp TR, Kahn DG, Warner NE: Detection and viability of tumor cells in peripheral blood stem cell collections from breast cancer patients using immunocytochemical and clonogenic assay techniques. Blood 1993, 82:2605-2610.

21. Cristofanilli M, Budd GT, Ellis MJ, Stopeck A, Matera J, Miller MC, Reuben JM, Doyle GV, Allard WJ, Terstappen L, Hayes DF: Circulating tumor cells, disease progression, and survival in metastatic breast cancer. New Engl J Med 2004, 351:781-791.

22. Cohen SJ, Punt CJ, lannotti N, Saidman BH, Sabbath KD, Gabrail NY, Picus J, Morse MA, Mitchell E, Miller MC, Doyle GV, Tissing H, Terstappen LW, Meropol NJ: Prognostic significance of circulating tumor cells in patients with metastatic colorectal cancer. Ann Oncol 2009, 20:1223-1229.

23. Cruz I, Ciudad J, Cruz JJ, Ramos M, Gómez-Alonso A, Adansa JC, Rodríguez C, Orfao A: Evaluation of multiparameter flow cytometry for the detection of breast cancer tumor cells in blood samples. Am J Clin Pathol 2005, 123:66-74

24. Fabisiewicz A, Kulik J, Kober P, Brewczyńska E, Pieńkowski T, Siedlecki JA: Detection of circulating breast cancer cells in peripheral blood by a twomarker reverse transcriptase-polymerase chain reaction assay. Acta Biochim Pol 2004, 51:747-755.

25. Turner RR, Giuliano AE, Hoon DS, Glass EC, Krasne DL: Pathologic examination of sentinel lymph node for breast carcinoma. World J Surg 2001, 25:798-805

26. Stathopoulou A, Gizi A, Perraki M, Apostolaki S, Malamos N, Mavroudis D, Georgoulias V, Lianidou ES: Real-time quantification of CK-19 mRNApositive cells in peripheral blood of breast cancer patients using the lightcycler system. Clin Cancer Res 2003, 9:5145-5151.

27. Chen CC, Hou MF, Wang JY, Chang TW, Lai DY, Chen YF, Hung SY, Lin SR: Simultaneous detection of multiple mRNA markers CK19, CEA, c-Met Her2/neu and hMAM with membrane array, an innovative technique with a great potential for breast cancer diagnosis. Cancer Lett 2006, 28:279-288.

28. Redding $\mathrm{WH}$, Coombes $\mathrm{RC}$, Monaghan $\mathrm{P}$, Clink HM, Imrie SF, Dearnaley DP, Ormerod MG, Sloane JP, Gazet JC, Powles TJ, Neville AM: Detection of micrometastases in patients with primary breast cancer. Lancet 1983, 3:1271-1274

29. Leather AJ, Gallegos NC, Kocjan G, Savage F, Smales CS, Hu W, Boulos PB, Northover JM, Phillips RK: Detection and enumeration of circulating tumour cells in colorectal cancer. Br J Surg 1993, 80:777-780.

30. Datta YH, Adams PT, Drobyski WR, Ethier SP, Terry VH, Roth MS: Sensitive detection of occult breast cancer by the reverse-transcriptase polymerase chain reaction. J Clin Oncol 1994, 12:475-482.

31. Alunni-Fabbroni M, Sandri MT: Circulating tumour cells in clinical practice: Methods of detection and possible characterization. Methods 2010, 50:289-297.

32. Muller CY, Cole LA: The quagmire of hCG and hCG testing in gynecologic oncology. Gynecol Oncol 2009, 112:663-672.

33. Nowak-Markwitz E, Jankowska A, Szczerba A, Andrusiewicz M: Human chorionic gonadotropin-beta in endometrium cancer tissue. Eur $J$ Gynaecol Oncol 2004, 25:351-354.

34. Nowak-Markwitz E, Jankowska A, Szczerba A, Andrusiewicz M, Warchoł JB: Localization of human chorionic gonadotropin beta subunit transcripts in ovarian cancer tissue. Folia Histochem Cytobiol 2004, 42:123-126.

35. Nowak-Markwitz E, Jankowska A, Andrusiewicz M, Szczerba A: Expression of beta-human chorionic gonadotropin in ovarian cancer tissue. Eur $\mathrm{J}$ Gynaecol Oncol 2004, 25:465-469.
36. Jankowska A, Gunderson SI, Andrusiewicz M, Burczynska B, Szczerba A Jarmolowski A, Nowak-Markwitz E, Warchol JB: Reduction of human chorionic gonadotropin beta subunit expression by modified U1 snRNA caused apoptosis in cervical cancer cells. Mol Cancer 2008, 7:26.

37. Nagy A, Schally AV: Targeting of cytotoxic luteinizing hormone-releasing hormone analogs to breast, ovarian, endometrial, and prostate cancers. Biol Reprod 2005, 73:851-859.

38. Jankowska AG, Andrusiewicz M, Fischer N, Warchol BJ: Expression of hCG and $\mathrm{GnRHs}$ and their receptors in endometrial carcinoma and hyperplasia. Int J Gynecol Cancer 2010, 20:92-101.

39. Muller V, Alix-Panabieres C, Pantel K: Insights into minimal residual disease in cancer patients: Implications for anti-cancer therapies. Eur J Cancer 2010, 46:1189-1197.

40. Sun YF, Yang XR, Zhou J, Qiu SJ, Fan J, Xu Y: Circulating tumor cells: advances in detection methods, biological issues, and clinical relevance. J Cancer Res Clin Oncol 2011.

41. Obermayr E, Sanchez-Cabo F, Tea MK, Singer CF, Krainer M, Fischer MB, Sehouli J, Reinthaller A, Horvat R, Heinze G, Tong D, Zeillinger R: Assessment of a six gene panel for the molecular detection of circulating tumor cells in the blood of female cancer patients. BMC Cancer 2010, 10:666.

42. Grünewald K, Haun M, Fiegl M, Urbanek M, Müller-Holzner E, Massoner A, Riha K, Propst A, Marth C, Gastl G: Mammaglobin expression in gynecologic malignancies and malignant effusions detected by nested reverse transcriptase-polymerase chain reaction. Lab Invest 2002, 82:1147-1153.

43. Aktas B, Kasimir-Bauer S, Heubner M, Kimmig R, Wimberger P: Molecular profiling and prognostic relevance of circulating tumor cells in the blood of ovarian cancer patients at primary diagnosis and after platinum-based chemotherapy. Int J Gynecol Cancer 2011, 21:822-830.

44. Su Y, Zheng L, Wang Q, Li W, Cai Z, Xiong S, Bao J: Quantity and clinical relevance of circulating endothelial progenitor cells in human ovarian cancer. J Exp Clin Cancer Res 2010, 29:27.

45. Olsen TG, Hubert PR, Nycum LR: Falsely elevated human chorionic gonadotropin leading to unnecessary therapy. Obstet Gynecol 2001, 98:843-845.

46. Hammond CB: False positive hCG. Obstet Gynecol 2001, 98:719-720.

47. Ballieux BE, Weijl NI, Gelderblom H, van Pelt J, Osanto S: False-positive serum human chorionic gonadotropin (HCG) in a male patient with a malignant germ cell tumor of the testis: a case report and review of the literature. Oncologist 2008, 13:1149-1154.

48. Cole LA, Laidler LL, Muller CY: USA hCG reference service, 10-year report. Clin Biochem 2010, 43:1013-1022.

49. Balic M, Dandachi N, Hofmann G, Samonigg H, Loibner H, Obwaller A, van der Kooi A, Tibbe AG, Doyle GV, Terstappen LW, Bauernhofer T: Comparison of two methods for enumerating circulating tumor cells in carcinoma patients. Cytometry B Clin Cytom 2005, 68:25-30.

50. Smirnov DA, Zweitzig DR, Foulk BW, Miller MC, Doyle GV, Pienta KJ, Meropol NJ, Weiner LM, Cohen SJ, Moreno JG, Connelly MC, Terstappen LW, O'Hara SM: Global gene expression profiling of circulating tumor cells. Cancer Res 2005, 65:4993-4997.

51. Chen SY, Huang YC, Liu SP, Tsai FJ, Shyu WC, Lin SZ: An overview of concepts for cancer stem cells. Cell Transplant 2010.

52. Gerlinger M, Swanton C: How Darwinian models inform therapeutic failure initiated by clonal heterogeneity in cancer medicine. $\mathrm{Br} J$ Cancer 2010, 103:1139-1143.

doi:10.1186/1479-5876-9-130

Cite this article as: Andrusiewicz et al:: CGB and GNRH1 expression analysis as a method of tumor cells metastatic spread detection in patients with gynecological malignances. Journal of Translational Medicine 2011 9:130. 